\title{
The Effect of Principal Leadership and Supervision Style on Teacher Work Motivation: A Regression Analysis
}

\author{
${ }^{1}$ Universitas PGRI Palembang, Palembang, Indonesia \\ * Corresponding author. E-mail: drbukmanlian@univpgri-palembang.ac.id
}

\begin{abstract}
The purpose of this study was to determine the effect of leadership style and supervision of principals on teacher work motivation. This research was conducted at Public Elementary School (SDN) Jejawi District, Ogan Komering Ilir Regency, Indonesia. The method used is descriptive quantitative. The results of the study concluded: (1) leadership style has a significant effect on teacher work motivation; (2) the supervision of the principal has a significant effect on teacher work motivation; and (3) the leadership style and supervision of school principals have a significant effect on teacher work motivation.
\end{abstract}

Keywords: Leadership Style, Supervision, Work Motivation

\section{INTRODUCTION}

At present, education is everyone's hope to be able to change the socio-economic conditions in each family. Through education, everyone hopes to be able to improve the standard of living and increase the social status in society. The high hopes and expectations of everyone regarding the role of education should also be the attention of education providers to continue to improve. The quality of education is one of the things that is important to continue to be addressed, with quality education, people's expectations can be achieved.

The preamble to the 1945 Constitution of the Republic of Indonesia in the fourth paragraph, clearly states that "the intellectual life of the nation" which means that the state must really ensure that every person or citizen has the right to become an intelligent human being, and that intelligence is used for the prosperity of the Indonesian nation [1]. As a form of government responsibility for the implementation of good education, a special regulation was issued regarding this matter. Special rules regarding education are published in the form of Law Number 20 of 2003 concerning the National Education System.

Education functions to develop abilities, shape the character and civilization of the Indonesian nation with dignity, in order to educate and develop a good community life. Education aims to develop the potential of students to become human beings who believe and fear God, have a noble character, are knowledgeable, healthy, independent, capable, creative, and become democratic and responsible citizens of Indonesia [2].

All existing authorities require a principal to have an effective and productive leadership style. Leadership as the art of persuading subordinates to do tasks with confidence and enthusiasm [3]. The leadership of a school principal will determine the quality of education held at the school. Therefore, it is very important for the principal to have a spirit to continue to innovate, because through innovation all solutions to problems that occur can be resolved properly.

A principal has the task of providing a positive influence, encouraging it to be better, providing guidance in carrying out tasks, providing direction, and being a driving force for teachers, education personnel, students, parents and other interested parties to work and play a role in achieving the stated goals [4]. This is clearly in line with the duties and authorities of the school principal.

The principal is wise in the distribution of duties and responsibilities. The principal is warmhearted and is always willing to help teachers and other employees by providing advice, suggestions, and instructions if needed [5]. As a leader, you should be able to give appreciation for all opinions, suggestions and even criticism conveyed by others. This is a consequence of using the democratic leadership style. Even so, the principal does not need to worry about obstacles in carrying out his duties. Because as a leader, the principal also has the authority to determine and make policies based on the results of the right formulation and analysis.

Therefore, the principal must also have and master the competencies as a school principal. One of these competencies is supervision. The ability to supervise all activities carried out at school must really be understood by the principal. Supervision is a coaching activity that is planned to assist teachers and other school staff to be able to do work effectively [6].

If a school principal is able to combine the right leadership style with the right supervision techniques, it can be strongly believed that the quality of education in the school he leads will be more optimal. It is important to understand that the success 
of a school principal in making quality education cannot be separated from the implementation of learning in the classroom. It is known together, that learning in class is carried out by the teacher. Teachers who have a position as professional staff have responsibilities that have been regulated in Law Number 14 of 2005 concerning Teachers and Lecturers Article 1 paragraph (1) states that teachers are professional educators. The main task of the teacher is to educate, guide, teach, train, direct, assess, and evaluate students.

Regulation of the Minister of Education and Culture Number 23 of 2017 article 1 paragraph (3) states that Teachers are professional educators, and have the main task of educating, guiding, teaching, directing, fostering, training, assessing and evaluating students, at the levels of early childhood education, basic education and secondary education [7]. Teachers as individual and social beings, of course, also have the desire or need encouragement to be able to carry out their duties properly. This desire or urge is often known as motivation.

So, it is clear that the relationship between the leadership style of a school principal and the competence of supervision that is owned, will have an impact on the motivation of the teacher as a subordinate who is responsible to the principal. Research conducted by Gumilar \& Munzir [9] states that leadership style can have an impact on teacher performance. Likewise, with research conducted by Priyono \& Rahayu [10], that leadership style has a positive and significant influence on career development.

Therefore, researchers believe that career alone can be influenced by leadership style, as well as work motivation. However, this is only an assumption before an in-depth analysis is carried out. To support the implementation of research, there are many expert opinions that are used as a basis, especially regarding work motivation, leadership style and supervision held by the principal.

\section{METHODS}

This research was conducted at SD Negeri Jejawi District, Ogan Komering Ilir Regency, Indonesia. This research was conducted in 2020. This research uses descriptive quantitative method. Nazir [11] argues that the descriptive method is a method of examining the status of a group of people, an object, a set of conditions, a system of thought, or a class of events in the present. Descriptive type of research is carried out with the aim of depicting facts about population-related information systematically and accurately. When using a descriptive research approach, the facts obtained from the research results will be presented as they should or as they are.

Likewise, with the opinion of Sugiyono [12], descriptive research is a form of research conducted with the aim of knowing the existence of independent variables, either in one particular variable or even more than one variable, without making a comparison or linking it with other variables. Quantitative research is a study that obtains numerical data or it can be extrapolated qualitative data. A quantitative approach is used to measure the variables in this study, namely the variables $\mathrm{X} 1, \mathrm{X} 2$ and $\mathrm{Y}$ and then to test the causal relationship between these variables.

There are 72 respondents spread across six schools. The data were obtained through a questionnaire arranged according to the indicators for each variable. Each stage of data collection through a questionnaire has been declared valid, because the questionnaire compiled has been tested for its validity and reliability. Data were analyzed by regression analysis.

\section{RESULTS AND DISCUSSION}

\subsection{Hypothesis Testing 1}

The $t$ value for the leadership style variable is $7,600>t_{\text {table }}$ is 1,994 (Table 1 ), which means that the leadership style has a positive and significant influence on teacher work motivation. The magnitude of the relationship and its influence can be seen in Table 2. The magnitude of the relationship between leadership style and teacher work motivation is $67.2 \%$, and is included in the strong relationship category. The determinant coefficient or the magnitude of the influence of the leadership style variable on teacher work motivation is $45.2 \%$, which means it has a high enough influence.

\section{Table 1 Test Results $\mathbf{t}$}

\begin{tabular}{|l|r|r|r|r|r|}
\hline \multirow{4}{*}{ Model } & \multicolumn{2}{|c|}{$\begin{array}{c}\text { Unstandardized } \\
\text { Coefficients }\end{array}$} & $\begin{array}{c}\text { Standardized } \\
\text { Coefficients }\end{array}$ & & \\
\cline { 2 - 4 } & \multicolumn{1}{|c|}{ B } & Std. Error & Beta & \multicolumn{1}{c|}{ S } & Sig. \\
\hline $1 \quad$ (Constant) & 30,968 & 6,491 & & 4,771 &, 000 \\
$\quad \begin{array}{l}\text { Gaya } \\
\text { Kepemimpinan }\end{array}$ &, 618 &, 081 &, 672 & 7,600 &, 000 \\
\hline
\end{tabular}

Table 2 Determinant Coefficient (H1)

Model Summary

\begin{tabular}{|l|c|r|r|r|}
\hline Model & \multicolumn{1}{|c|}{ R } & R Square & Adjusted R Square & Std. Error of the Estimate \\
\hline 1 &, $672^{\mathrm{a}}$ &, 452 &, 444 & 1,82968 \\
\hline
\end{tabular}

b. Dependent Variable: Motivasi Keria Guru

\subsection{Hypothesis Testing 2}

For the principal supervision variable $t_{\text {count }}>$ $\mathrm{t}_{\text {table }} ; 4,400>1,994$ (Table 3 ). So it is concluded that the supervision of the principal has a positive and significant effect on teacher work motivation. The magnitude of the relationship and the magnitude of the influence of principal supervision on teacher work motivation is seen in Table 4. The correlation coefficient or the magnitude of the relationship between principal supervision and teacher work motivation is $46.5 \%$. The magnitude of the relationship is in a fairly close category. The determinant coefficient or the magnitude of the influence of the principal's supervision variable on teacher work motivation is $21.7 \%$ and is included in the low influence category. 
Table 3 Test Results t

\begin{tabular}{|c|c|c|c|c|c|}
\hline \multirow[b]{2}{*}{ Model } & \multicolumn{2}{|c|}{$\begin{array}{l}\text { Unstandardized } \\
\text { Coefficients }\end{array}$} & \multirow{2}{*}{$\begin{array}{c}\begin{array}{c}\text { Standardized } \\
\text { Coefficients }\end{array} \\
\text { Beta }\end{array}$} & \multirow[b]{2}{*}{$\mathrm{t}$} & \multirow[b]{2}{*}{ Sig. } \\
\hline & B & Std. Error & & & \\
\hline \begin{tabular}{|ll}
1 & (Constant)
\end{tabular} & 47,119 & 7,538 & & 6,251 &, 000 \\
\hline $\begin{array}{l}\text { Supervisi Kepala } \\
\text { Sekolah }\end{array}$ & & ,094 & ,465 & 4,400 & ,000 \\
\hline
\end{tabular}

Table 4 Determinant Coefficient (H2)

Model Summary ${ }^{b}$

\begin{tabular}{|c|c|c|c|c|}
\hline Model & $\mathrm{R}$ & $\mathrm{R}$ Square & Adjusted R Square & Std. Error of the Estimate \\
\hline 1 &, $465^{\mathrm{a}}$ &, 217 &, 205 & 2,18771 \\
\hline
\end{tabular}
a. Predictors: (Constant), Supervisi Kepala Sekolah
b. Dependent Variable: Motivasi Kerja Guru

\subsection{Hypothesis Testing 3}

$\mathrm{F}_{\text {count }}$ of $28.661>\mathrm{F}_{\text {table }}$ of 3.129 (Table 5), which means that there is a significant effect of leadership style and supervision of principals on teacher work motivation, with a regression coefficient of 0.674 . The contribution of the leadership style and supervision of the principal to the work motivation of teachers was $45.4 \%$ (Table 6).

Table 5 F Test Results

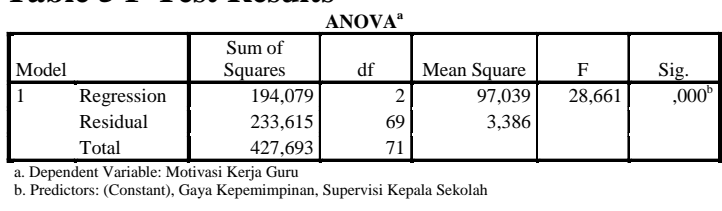

Table 6 Determinant Coefficient (H3) Model Summary

\begin{tabular}{|l|c|r|r|r|}
\hline Model & R & R Square & Adjusted R Square & Std. Error of the Estimate \\
\hline 1 &, $674^{\mathrm{a}}$ &, 454 &, 438 & 1,84003 \\
\hline
\end{tabular}
a. Predictors: (Constant), Gaya Kepemimpinan, Supervisi Kepala Sekolah
b. Dependent Variable: Motivasi Kerja Guru

The results of this study certainly confirm some of the previous studies that have been conducted, such as Rukmana's research [13]. There are many other studies which are also confirmed through this research. A similar study was also conducted by Lukman, et al., [14], that principal leadership has a positive relationship with motivation. In fact, Salwa et al. [15] used the principal's leadership as a variable that was tested with motivation. For this reason, in essence the two variables are related.

That is, the principal leadership variable is able to consistently have an impact on the work motivation of teachers who are in their responsibility. Especially when studying the results of a study by Syahril [16], that the principal is not only able to optimize motivation, but also plays a role in improving performance. That is why motivation is an intermediary variable for achieving good performance through good leadership.

The results of this study confirm the previous research conducted by Zamroni, et al., [17] which concluded that there is an influence of leadership style on teacher work motivation. The same thing is also related to the research of Tifyani [18], Gumilar \& Munzir [9], Budiyono, et al., [19] that work motivation can be influenced by many factors such as the results obtained from the research that has been done. Handayani's research, et al., [20] stated that supervision has a positive impact on performance, which assumes that performance will be good if someone has good motivation. That is why motivation becomes a moderating variable in the study.

When analyzed in research conducted by Alhusaini, et al., [21], that good work motivation can have a positive impact on performance. Leadership is the key in school organization [22]-[27]. Therefore, it is very relevant if the researcher also recommends increasing work motivation so that the implications for performance are more optimal. Likewise, with the studies produced by Hernita, et al., [28] and Sultoni, et al., [29], that basically motivation is an important factor that has an impact on one's performance. Therefore, usually the motivation variable is a variable that tests other variables, in contrast to this study, it actually tests motivation.

\section{CONCLUSION}

The results of data analysis and processing, this study concluded that the variable of leadership style and supervision of the principal has a significant influence on teacher work motivation. The results of this research can inspire other researchers to participate in testing the consistency of the results of the research conducted. This is because researchers believe that in different situations and conditions, research results anomalies may occur. This is precisely what is interesting to be examined more deeply. That is why it is highly recommended to conduct a similar study by paying attention to other aspects that have not been carried out in this research.

\section{REFERENCES}

[1] Pemerintah Republik Indonesia, "Undangundang Nomor 14 Tahun 2005 tentang Guru dan Dosen". Jakarta: Deputi Menteri Sekretaris Negara Bidang Perundang-undangan, 2005.

[2] Kementerian Pendidikan Nasional, "Undangundang Nomor 20 Tahun 2003 tentang Sistem Pendidikan Nasional". Jakarta: Kementerian Pendidikan Nasional, 2003.

[3] E. Mulyasa, "Menjadi kepala sekolah profesional". Bandung: Remaja Rosdakarya, 2013.

[4] M. Kristiawan, D. Safitri, and R. Lestari, "Manajemen Pendidikan". Yogyakarta: Deepublish, 2017.

[5] S. Indrafachrudi, "Bagaimana memimpin sekolah yang efektif”. Bogor: Ghalia Indonesia, 2006.

[6] M. Hanief, "Menggagas teknik supervisi klinik sebagai upaya peningkatan mutu pembelajaran". Vicratina (Jurnal Kependidikan dan Keislaman), Vol. 10, No. 2, p. 1-19, 2016. 
[7] Kementerian Pendidikan dan Kebudayaan, "Peraturan Menteri Pendidikan dan Kebudayaan Nomor 23 Tahun 2017 tentang Hari Sekolah". Jakarta: Kementerian Pendidikan dan Kebudayaan, 2017.

[8] S. P. Siagian, "Teori motivasi dan aplikasinya". Jakarta: Bumi Aksara, 2008.

[9] G. G. Gumilar, and T. Munzir, "Pengaruh gaya kepemimpinan kepala sekolah terhadap kinerja guru SMA Global Indo-Asia Batam”. Jurnal Dimensi, Vol. 7 No. 2, p. 255-266, 2018.

[10] Priyono, and A. Rahayu, "Pengaruh gaya kepemimpinan kepala sekolah, motivasi kerja, dan kedisiplinan terhadap pengembangan karier guru SMK di Kabupaten Boyolali”. QUALITY, Vo. 4 No. 1, p. 25-44, 2016.

[11] M. Nazir, "Metode penelitian". Jakarta: Ghalia Indonesia, 2011.

[12] Sugiyono, "Metode Penelitian Kualitatif, Kuantitatif dan R\&D”. Bandung: Alfabeta, 2017.

[13] A. Rukmana, "Pengaruh gaya kepemimpinan kepala sekolah dan motivasi kerja guru terhadap kinerja guru". Coopetition, Vol. 9 No. 1, 77-93, 2018 .

[14] Lukman, B. Lian, and A. Puspitasari, "The Influence of Principal's Leadership and Work Motivation toward Teacher's Performance". International Journal of Progressive Sciences and Technologies (IJPSAT), Vol. 22 No. 1, 376-379, 2020.

[15] Salwa, M. Kristiawan, and B. Lian, "The effect of academic qualification, work experience and work motivation towards primary school principal performance". International Journal of Scientific \& Technology Research, Vol. 8, No. 8, p. 969-980, 2019.

[16] B. Syahril, "Pengaruh Gaya Kepemimpinan Kepala Sekolah, Sikap Guru dan Disiplin Guru Terhadap Kinerja Guru SMA Negeri di Kota Manna Bengkulu Selatan”. Bengkulu: Universitas Bengkulu, 2013.

[17] M. Zamroni, Nurkolis, and Y. Yuliejantiningsih, "Pengaruh gaya kepemimpinan kepala sekolah dan motivasi kerja guru terhadap kinerja guru SMP Se-Kecamatan Kersana Kabupaten Brebes". e-jurnal UPGRIS, 2017.

[18] Tifyani, "Pengaruh gaya kepemimpinan dan kemampuan supervisi kepala madrasah terhadap kinerja guru pada MI Swasta se-Kecamatan Sumberlawang Kabupaten Sragen Tahun 2015/2016". Surakarta: Institut Agama Islam Negeri Surakarta, 2016.

[19] Budiyono, B. Lian, and H. Fitria, "The Influence of Principal Supervision and Organizational Climate toward Teacher's Performance". Electronic Research Journal of Social Sciences and Humanities, Vol. 2, No. 2, p. 172-187, 2020.
[20] P. Handayani, I. Prasetyo, and R. Wiroko, "Pengaruh Supervisi Kepala Sekolah dan Lingkungan Kerja Terhadap Profesionalisme Guru dan Kinerja Guru SMP Negeri 1 Gondang Bojonegoro". MAP (Jurnal Manajemen dan Administrasi Publik), Vol. 1, No. 3, p. 328-341, 2018.

[21] A. Alhusaini, M. Kristiawan, and S. Eddy, "Pengaruh motivasi kerja dan disiplin kerja terhadap kinerja guru". Jurnal Pendidikan Tambusai, Vol. 4, No. 3, p. 2166-2172, 2020.

[22] I. Gunawan, "Instructional Leadership Profile of Junior High School's Principal (A Case Study of Junior High School in Malang)". International Research-Based Education Journal, Vol. 1, No. $1,2017$.

[23] A. Prastiawan, I. Gunawan, A. P. Putra, D. A. Dewantoro, P. S. Cholifah, N. L. S. Nuraini, ... and E. Surahman, "School Leadership Skills in Educational Institutions. In 6th International Conference on Education and Technology (ICET 2020) (pp. 438-441), Atlantis Press, 2020

[24] I. Gunawan, I. Bafadal, and A. Nurabadi, "School Leadership Strategy in Excellent Schools". In 6th International Conference on Education and Technology (ICET 2020) (pp. 210-215), Atlantis Press, 2020.

[25] A. N. Faizah, I. Gunawan, I. Bafadal, and A. Timan, "The Relationship between Learning Leadership and Teacher Performance: A Correlation Analysis". In 1st International Conference on Information Technology and Education (ICITE 2020) (pp. 599-602), Atlantis Press, 2020.

[26] I. Bafadal, I. Gunawan, and A. Nurabadi, "Leadership in Excellent School: A Qualitative Study". In 1st International Conference on Information Technology and Education (ICITE 2020) (pp. 63-66), Atlantis Press, 2020.

[27] D. E. Kusumaningrum, R. B. Sumarsoso, and I. Gunawan, "Budaya Sekolah dan Etika Profesi: Pengukuran Pemberdayaan Sumber Daya Manusia Sekolah dengan Pendekatan Soft System Methodology". JAMP: Jurnal Administrasi dan Manajemen Pendidikan, Vol. 2, No. 3, p. 90-97, 2019.

[28] R. Hernita, Y. Arafat, and Missriani, "The Effect of Work Motivation, School Culture and School Based Management on Teacher's Performance". Electronic Research Journal of Social Sciences and Humanities, Vol. 2, No. 2, p. 188-202, 2020.

[29] M. Sultoni, B. Lian, and Mulyadi, "The Influence of School Based Management and Work Motivationtowards Teacher's Performance". International Journal of Educational Review, Vol. 2, No. 2, p. 183-191, 2020. 